\title{
高力ボルト摩擦接合ならびに同接合法による梁継手の 弾塑性性状とその安全性に関する実験的研究 (2)
}

(梁継手の繰返し荷重試験（続)）

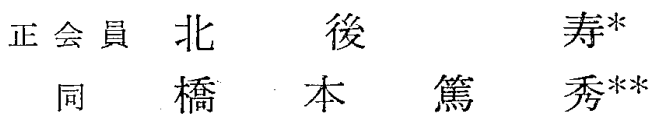

\section{1. 概 要}

論文報告集 128 号（41 年月 10 号）には，高力ボル 卜摩擦接合梁継手の繰返し曲げ嗬重試験についてその詳 細を述べたが，今回はその後行なった同様な梁継手に関 する 2 種類の異なった載荷状態における実験結果につい

て報告する。

実験 I は，H 型鋼の梁継手に剪断型の繰返し荷重を加 えた試験についてである。

実験 II は，組立工型梁継手に曲げと剪断が同時に作 用する一般の応力状態における，繰返し荷重時の弾塑性 性状に関するものである。

実験Ｉは H-294×200×8×12 を用い，高力ボルトは JIS 規格 2 種 BW $5 / 8$ 中とし，試験体はボルト本数を変 えた 2 個と無継手のもの 1 個計 3 個につマて行なった。

実験 II はプレートの組立による I - $300 \times 150 \times 6 \times 9$ を 用、，高力ボルトは JIS 規格 3 種 BW $3 / 4 \phi$ とし，試 験体はボルト本数を変えた 2 個と無継手のもの 1 個計 3 個について行なった。

梁長は何冯も $4.800 \mathrm{~m}$ で, 荷重は正負両方向の繰返 しとし，測定注梁の泋みとボルト軸力の変化に主力を注 Wた。

なお実験 II では剪断力を同時に作用させるため接合 部を最大曲げモーメント位置から若干ずらしたので，試
験体における接合部曲げ応力はやや低応力の状態となっ ている。

\section{2. 試 験 体}

試験体種別は表一1 に示す通りで，その形状寸法等を
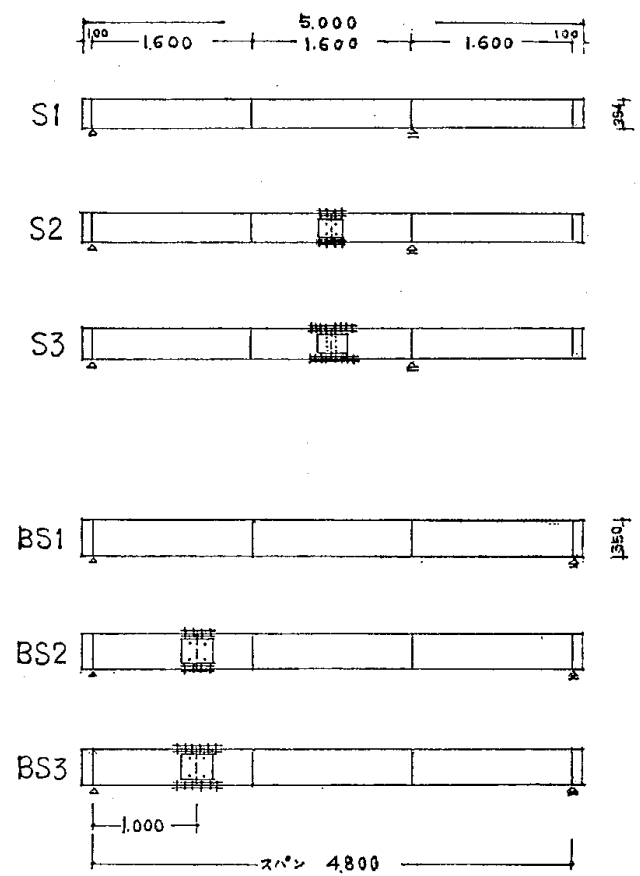

[実 験 I]

図一1 試験体の形状

表一 1 試 験 体種別

\begin{tabular}{|c|c|c|c|c|c|c|c|c|c|c|c|c|c|}
\hline \multirow{3}{*}{\multicolumn{2}{|c|}{ 試験体記号 }} & \multirow{2}{*}{ 材 } & \multirow{2}{*}{ 種 } & \multirow{3}{*}{ 摩撚面 } & \multirow{2}{*}{\multicolumn{2}{|c|}{ 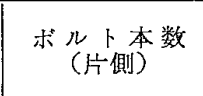 }} & \multirow{2}{*}{\multicolumn{2}{|c|}{ 添 $\underset{(\mathrm{mm})}{\text { 板 }}$}} & \multicolumn{4}{|c|}{ 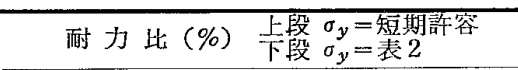 } & \multirow{3}{*}{ 備 } \\
\hline & & & & & & & & & \multicolumn{2}{|l|}{ 本 } & \multicolumn{2}{|l|}{ 添 } & \\
\hline & & 部 材 & ボル卜 & & フランシ| & ウェブ & フランシ & ウェブ & 全断 面 & $\begin{array}{l}\text { 我ル卜突 } \\
\text { 除 }\end{array}$ & 全断面 & $\begin{array}{l}\text { 术ルト穴 } \\
\text { 控 }\end{array}$ & \\
\hline 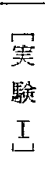 & $\begin{array}{l}\text { S1 } \\
\text { S2 } \\
\text { S3 }\end{array}$ & $\operatorname{SS} 41$ & $\begin{array}{l}2 \text { 種 } \mathrm{B} \\
\mathrm{B} / 8\end{array}$ & 2 面 & $\begin{array}{l}- \\
8 \\
16\end{array}$ & $\begin{array}{r}- \\
2 \\
4\end{array}$ & $\begin{array}{l}- \\
\text { 外 } 6 \\
\text { 外 } \\
\text { 外 } \\
\text { 内 }\end{array}$ & $\begin{array}{r}- \\
6 \\
6\end{array}$ & $\begin{array}{r}- \\
28.9 \\
23.4 \\
57.7 \\
46.8\end{array}$ & $\begin{array}{r}- \\
28.9 \\
23.4 \\
57.7 \\
46.8\end{array}$ & $\begin{array}{r}- \\
24.5 \\
23.0 \\
49.1 \\
46.0\end{array}$ & $\begin{array}{l}24.5 \\
23.0 \\
49.1 \\
46.0\end{array}$ & $\begin{array}{l}\text { 本体 } \mathrm{H}-294 \cdot 200 \cdot 8 \cdot 12 \\
\text { ボルト締付力 } 9 \mathrm{t} \\
\mu=0.43\end{array}$ \\
\hline 䨋 & $\begin{array}{l}\text { BS } 1 \\
\text { BS } 2 \\
\text { BS } 3\end{array}$ & SM 50 & $\begin{array}{c}3 \text { 種 } \mathrm{B} \\
\mathrm{B}\end{array}$ & 2面 & $\begin{array}{r}- \\
8 \\
12\end{array}$ & $\begin{array}{l}- \\
2 \\
2\end{array}$ & $\begin{array}{l}- \\
\text { 外 } 6 \\
\text { 内 } 9 \\
\text { 外 } 6 \\
\text { 内 } 9\end{array}$ & $\begin{array}{l}-- \\
6 \\
6\end{array}$ & $\begin{array}{r}- \\
87.7 \\
72.2 \\
105.5 \\
86.7\end{array}$ & $\begin{array}{r}- \\
100.5 \\
82.7 \\
121.0 \\
100.0\end{array}$ & $\begin{array}{r}- \\
62.7 \\
51.5 \\
75.5 \\
62.0\end{array}$ & $\begin{array}{r}- \\
84.9 \\
69.8 \\
102.2 \\
84.1\end{array}$ & 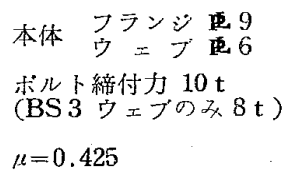 \\
\hline
\end{tabular}

*日本電信電話公社 建築技術研究室 **東京工業大学大学院 (昭和 41 年 11 月 24 日本稿受理，討諭期限昭和 42 年 8 月末日)

注）本論文は下記大会報告論文を詳述し総合的に検討したものである。 北後, 藤本, 橋本 : 高力ボル卜摩擦接合梁の繰返し荷重試験, 論報号外（昭 40.9） 北後, 藤本, 橋本 : 


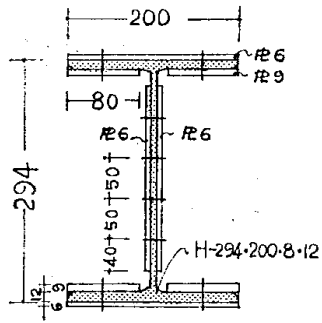

[実 験 I]

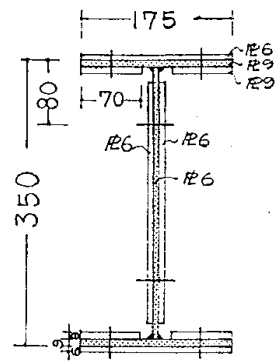

[笑 駼 II]
図一2 試験体断面詳細

図一1, 図一2 に示した。

表一1 にある耐力比は，継手部に括ける接合強度と部 材強度の比を表わし，実験Ｉでは部材強度として断面の 降伏抵抗剪断力を次式により求めた。

$$
Q_{Y}=j \cdot t \cdot f_{S} \quad \succ ね f_{S}=1 / \sqrt{3} \sigma_{Y}
$$

実験 II では部材強度は断面の降伏抵抗モーメントをと った。なお接合強度の之り係数 ( $\mu$ ) 洁基礎試験の結果か ら実験Iでは 0.43 ，実験 II では 0.425 としている。

使用鋼材は実験 I が SS 41，実験 II が SM 50 であり その材料試験結果は表一 2 に示す通りである。また高力 ボルトの機械的性質その他を表一3 に示す。

表-2 使胜鋼材の機械的性質

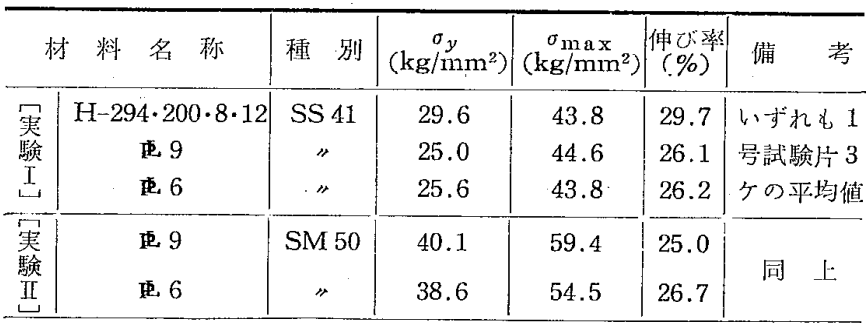

部材の摩摖面はすべてサンドブラスト仕上とした。

\section{3. 実験方法}

載渮は東京工業大学のアムスラ一型 $200 \mathrm{t}$ 曲げ圧縮試 験機を用い，図-3 の如く 2 点集中荷重による両振り繰 返し載荷方法をとった。何重サイクルの標準は次の通り である。
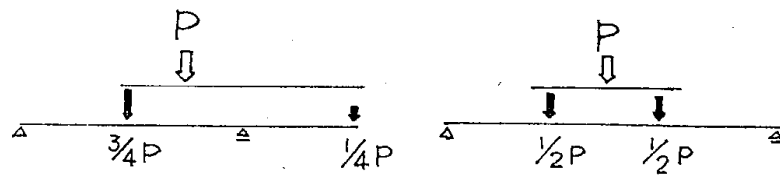

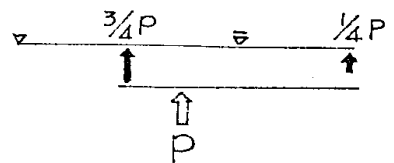

[実験 I]

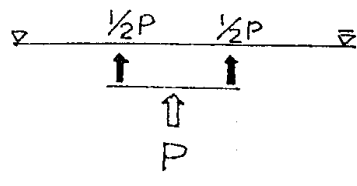

[実験 II]
図一3 載 荷 方 法 i） 0 一十（ボルト摩擦力から決る）长期許容荷重一0

ii） 0 一十(ボルト摩擦力加ら決る) 短期許容偖重一0

iii） 0 -ー（ボルト摩擦力から決る）短期許容何重一0

iv） 0 - + 记り一塑性率 2-0

v) 0 - - 亡 り一塑性率 $2-0$

vi) 0 -十之り一破壊

高力ボルトはスナップオン型トルクレンチを用いて締 付け，実験 Iでは軸力 $9 \mathrm{t}$ ，実験 II では軸力 $10 \mathrm{t}$ (BS3 のウェブのみ $8 \mathrm{t}$ ）とした。これの確認はボルト軸部に 貼布したワイヤストレンゲージにより行なった。ワイヤ ストレンゲージの貼布していないものについてはトルク 係数に応じたトルク值まで締付け，各ボルトの導入軸力 に差を生ぜしめないよら注意した。

梁の挥みは $1 / 100 \mathrm{~mm}$ ダイヤルゲージと変位計により 中央および雨荷重点，継手部について測定した。高力ボ ルトの軸力変化は，片側の全ボルトに貼布したワイヤス トレンゲージの挙動により追求した。なお補助的に断面 のひずみ度をワイヤストレンゲージを用いて観测した。

実験中の模様を写真一1 に示す。

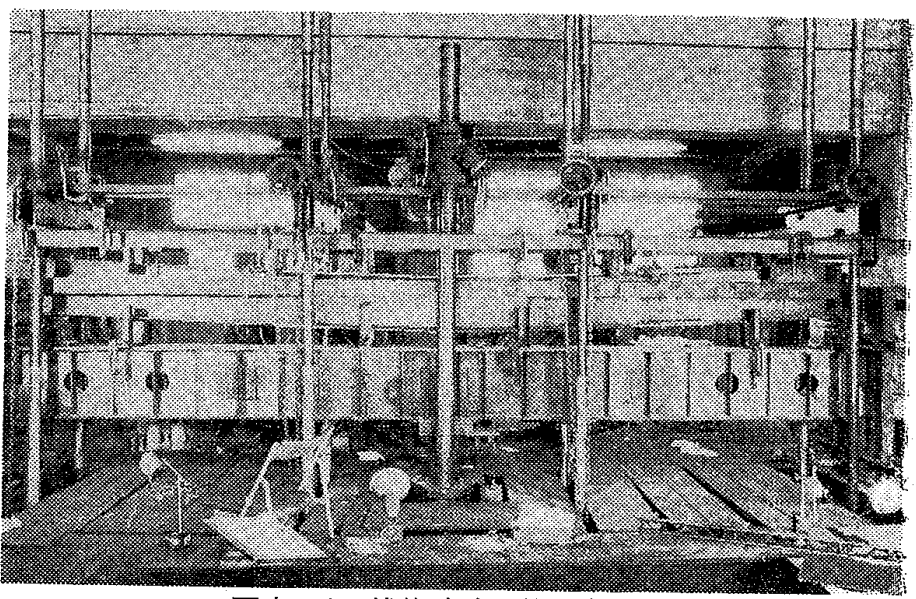

写真-1 載荷試験の状沉(BS 3)

\section{4. 実験 結果}

\section{1 主运り荷重}

実験結果は表一-4 に示す通りであり，理論倬は実験 I では耐力比の算出法によって計算した荷重, 実験 II で は $P_{0}, P_{S}$ は第 1 報に示した方法によって算定した得重. $P_{B}$ はフランジ部高力ボルトは曲げのみに，ウェブ部高 力ボルトは剪断のみに抵抗するものとして算出した荷重 となっている。実験值は最初に之った荷重（主之り荷 重）または降伏荷重を表わしている。

\section{2 荷重搷夕曲線}

各試験体の荷重暁み曲線の一例は，図一4の通りであ る。

表一3 高力ボルトの機械的性質その他

\begin{tabular}{|c|c|c|c|c|c|c|c|c|c|c|}
\hline 材 & 料 & 称 & 程 & $\begin{array}{c}\sigma_{y} \\
\left(\mathrm{~kg} / \mathrm{mm}^{2}\right)\end{array}$ & $\left(\begin{array}{c}\sigma \max \\
\left(\mathrm{kg} / \mathrm{mm}^{2}\right)\end{array}\right.$ & $\begin{array}{c}\text { 伸 } \\
(\%)\end{array}$ & $\begin{array}{c}\text { 絞 } \\
(\%)\end{array}$ & 度 & ナット硬度 & 座金硬度 \\
\hline [実験 I] & 2 種 & $\mathrm{BW} 5 / 8 \phi$ & $\mathrm{F} 9 \mathrm{~T}$ & 82.5 & 100.4 & 18.9 & 53.1 & HRC 29.2 & HRB 91.8 & HRC 41.8 \\
\hline [実験 II] & 3 種 & $\mathrm{BW} 3 / 4 \phi$ & $\mathrm{F} 11 \mathrm{~T}$ & 115.3 & 120.3 & 17.8 & 62.4 & HRC 35.6 & HRB 99.7 & HRC 45.9 \\
\hline
\end{tabular}


表一4 実 験 結 果一 覧 表

\begin{tabular}{|c|c|c|c|c|c|c|c|c|c|}
\hline \multirow{3}{*}{$\begin{array}{l}\text { 試 験 枿 } \\
\text { 記 㞻 }\end{array}$} & \multicolumn{4}{|c|}{ 理 論 值 $[P$ 理 $](\mathrm{t})$} & \multirow{3}{*}{$\begin{array}{c}\text { 実 験 值 } \\
{[P \text { 実 }]} \\
(\mathrm{t})\end{array}$} & \multirow{3}{*}{$P$ 実 $/ P$ 理 $\min$} & \multirow{3}{*}{$\begin{array}{c}\text { 最大荷重 } \\
\text { (t) }\end{array}$} & \multirow{3}{*}{ 実 験 後 の 試 } & \multirow{3}{*}{ 験 体 の 状 況 } \\
\hline & \multirow{2}{*}{$P_{0}$} & \multirow{2}{*}{$P_{S}$} & \multicolumn{2}{|c|}{$P_{B}$} & & & & & \\
\hline & & & 剪 断 & 曲げ & & & & & \\
\hline $\mathrm{S1}$ & 66.6 & 一 & - & - & $(64.0)$ & $(0.96)$ & 65.0 & 荷重点付近のフランシ厌縮座屈 & \\
\hline $\mathrm{S} 2$ & 66.6 & 67.6 & 15.5 & - & 21.0 & 1.35 & 56.0 & 上 & ウェブ面にうり \\
\hline S3 & 66.6 & 67.6 & 31.0 & - & 34.3 & 1.11 & 67.8 & 同 & 上 \\
\hline BS 1 & 31.2 & - & - & - & $(32.0)$ & $(1.03)$ & 35.0 & 最大曲げモーメント部極部座屈 & \\
\hline BS 2 & 27.3 & 32.2 & 34.0 & 22.6 & $\begin{array}{c}33.2 \\
(32.0)\end{array}$ & 1.47 & 35.9 & 同 & フランジ面にさり \\
\hline BS 3 & 27.3 & 32.2 & 27.2 & 33.9 & $(31.9)$ & $(1.17)$ & 33.7 & 最大曲げモーメント部極部座屈 & 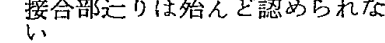 \\
\hline
\end{tabular}

$P_{0}$ : 目材の降伏強度によって決る荷重（ボルト穴控除断面皘を対象） $P_{B}$ ：ボルト摩擦力に上って決る荷重

$P_{S}:$ 添板の降伏強度に上って決る荷重（ポルト穴控除断面積を対象）（）は目材降伏荷重を示す
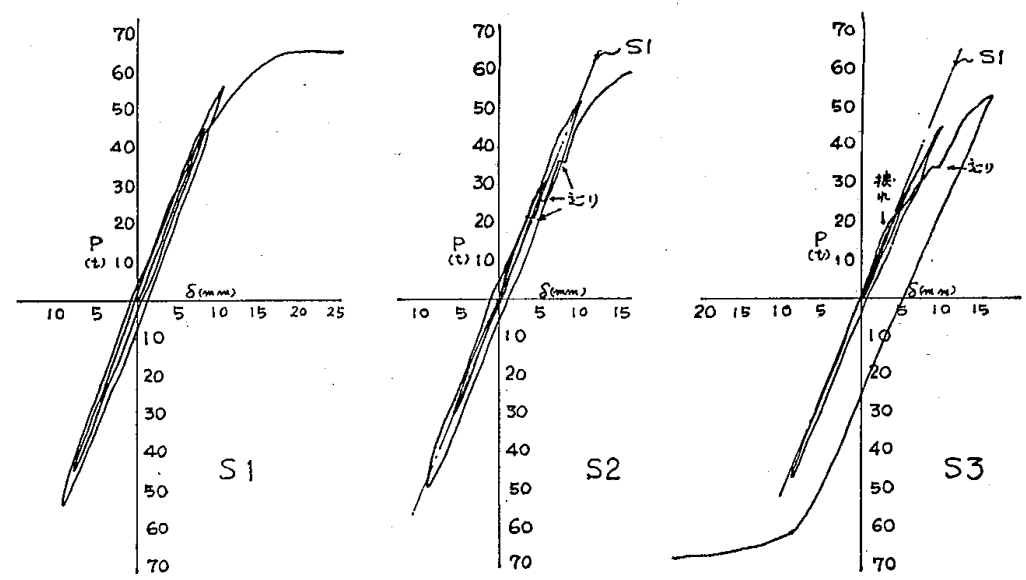

[実験 I 荷 重 点]
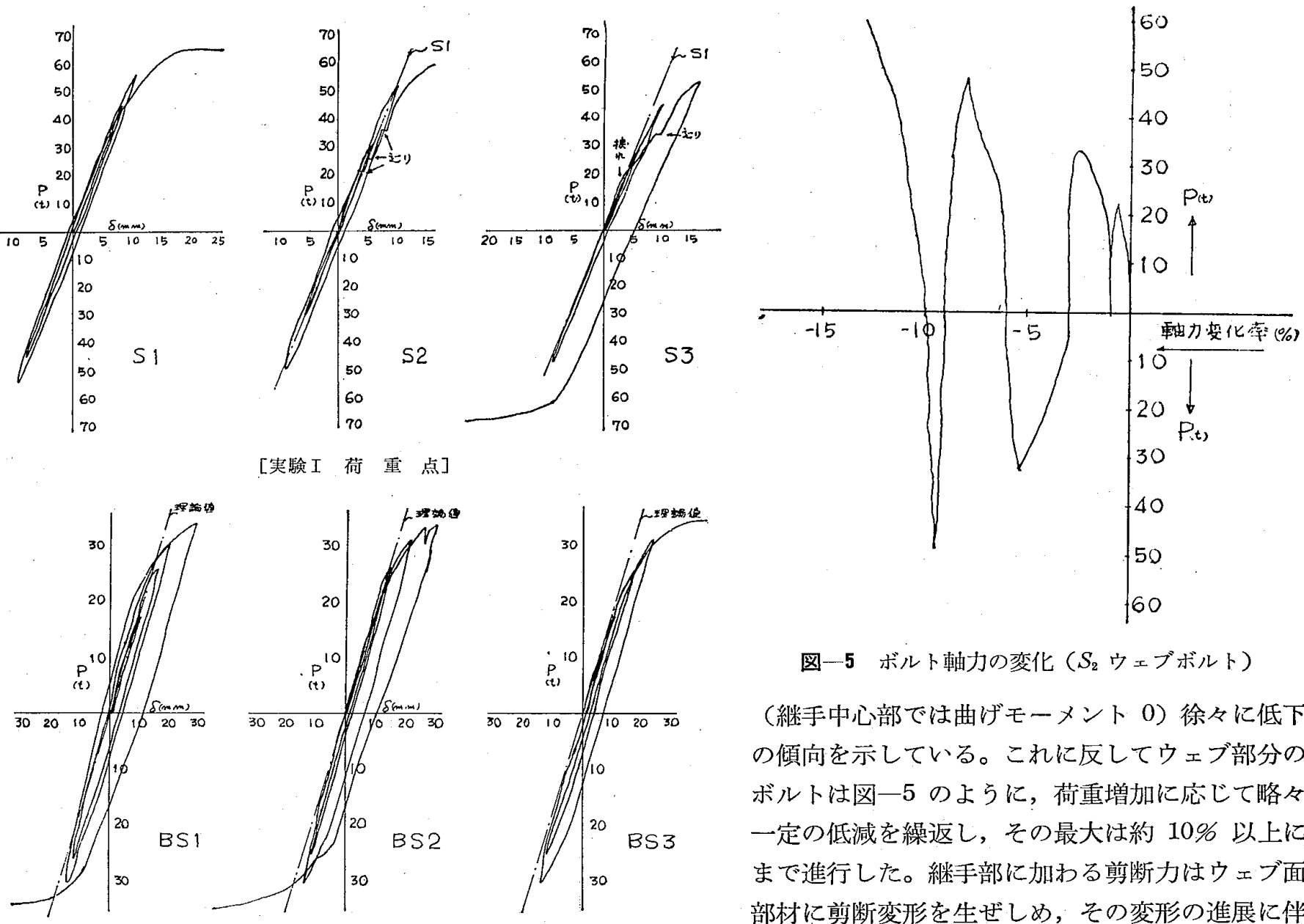

図一5 ボルト軸力の変化 $\left(S_{2}\right.$ ウェブボルト)

（継手中心部では曲げモーメント0）徐々に低下 の傾向を示している。これに反してウェブ部分の ボルトは図一5 のように，荷重増加に応じて略々 一定の低減を繰返し，その最大は約 10\% 以上に まで進行した。継手部に加わる剪断力はウェブ面 部材に剪断変形を生ぜしめ, その変形の進展に伴 ならボルト軸力の挙動が観測されたものと考えら

图一4 荷重, 暁み曲線

実験 Iではウェブ部分ボルトの之りによる変形は極め て小さく，摩擦音を発しながら荷重は落ちずにそのまま 上昇を続ける。これはフランジ部における拘束が非常に 大きく効いているものと判断される。この点曲げ荷重試 験における鋸歯状の変形性状とは, 全然その趣を異にし ているといえる。

実験 II では部材降伏をで高力ボルトの之り現象は見 られず，無継手のものと殆んど変らない曲線の性状とな っている。

\section{3 ボルト軸力の変化}

実験 Iでは, フランジ部のボルト满重の小さい間は 動かず，大きくなるにつれて外側が曲げの影響を受けて

れる。

実験 II では, フランジ部のボルトは曲げ荷重時の挙 動と全く等しく，ウェブ部のボルトは実験 I の場合と同 ご動きを示す。ただ之り時において引張側に近い方のウ ェブ部ボルトは非常に激しい低減の様相を示し, 丁度フ ランジ部の引張側ボルトと同じような状態となる。これ はウェブ部ボルトも曲げに抵抗している事を意味してい るものと思われる。ボルト軸力の変化に関し, 導入時, 載 荷開始時, 載荷終了時をそれぞれ測定記録したのが表一 5 である。BS 2 は之り現象が認められた試験体でその 位置によって大分差があり最大 $30 \%$ 近くの軸力低下が 生じている。BS 3 は迄りがなかった試験体であるが, 比較的平均化した值として約 $15 \%$ の軸力低下が見られ 
表一5 BS型ボルト軸力の变化

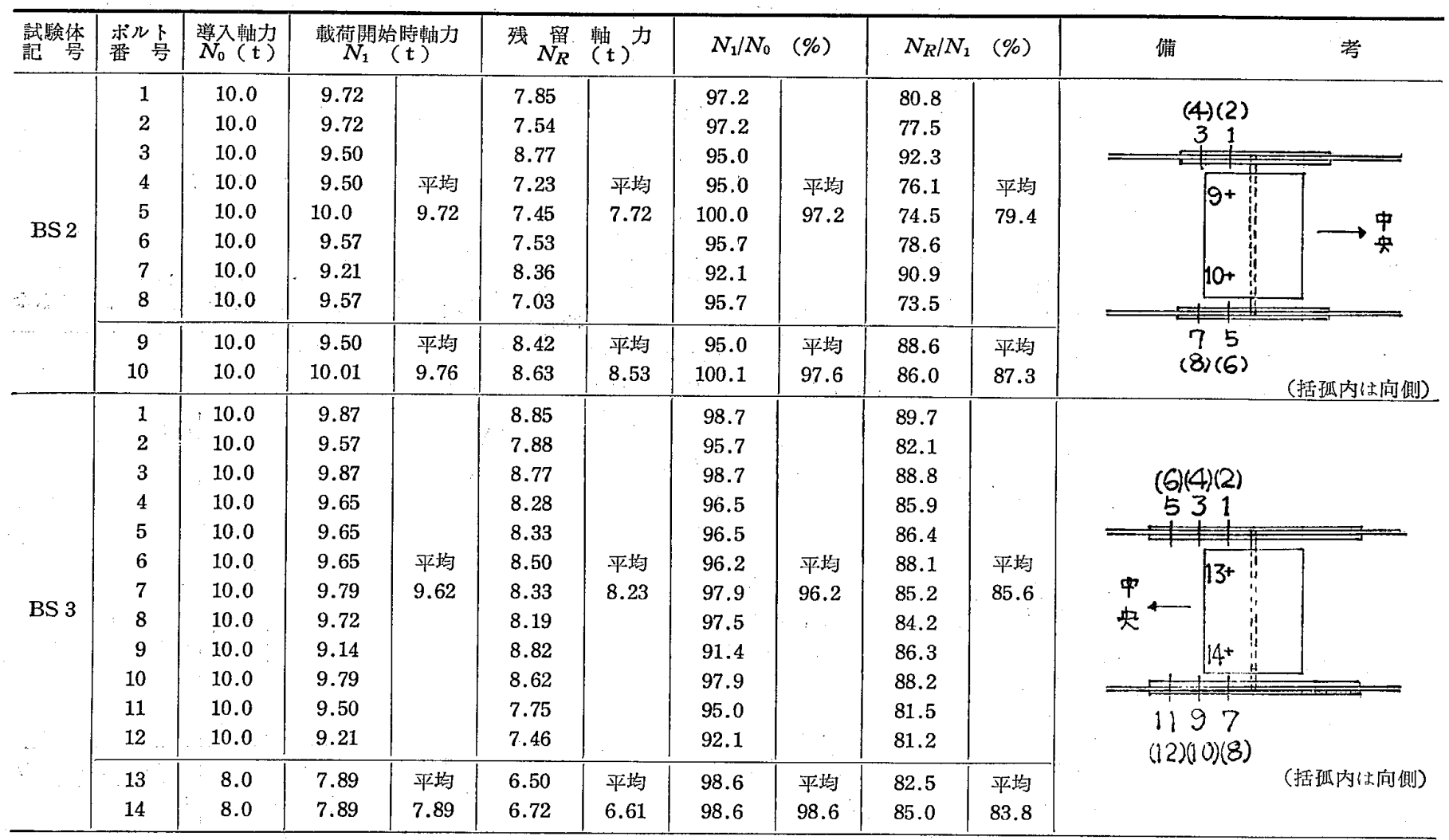

る。

\section{5. 実験結果の考察}

\section{1 接合部の強度}

表一4 から明らかなよらに，実験值は理論值よりかな り高く, 初期之りに対古它安全性は施工条件さえ整って いれば十分であると考えられる。

実験Iの主之り荷重は，いすれも最終サイクルで観測 されたもので, 既に荷重履歴を経た後に生じており, 繰 返しによる影響が表われたものと見られる。またこの場 合フランジ面の接合が十分であるので，ウェブ面の摩擦 功切れてもその変形は極く小さく，耐力上問題はなさそ うである。

実験 II では，BS2・は曲げによる高力ボルトの迄り， BS 3 は剪断による之りがそれぞれ 先衍するよう計画し たが，結果はともに部材の降伏で決ってしまらといらこ ととなった。荷重泋み曲線からも無継手の梁と殆んど変 らない性状を示しており：この種継手の強度は非常に高 いものと判断される。なお BS 3 の最終サイクル時に, 28.5 七 侍重拖み曲線には表われない主りが生じたが， これは実験工と同様なことと解釈できる。

\section{2 剛 性}

荷重搷夕曲線注，実験 I では無継手の梁 S 1, 実験 II では暁み理論值と比較してそれぞれその変形曲線の傾斜 は殆んど変らす，極めて高い剛性を有することが判明し た。

ここことは，曲げ荷重時の結果と併わせ考えて，高力 ボルト摩擦接合梁継手に関し，它の剛性確保といら面か
ら，本接合形式の優秀性が明確になったものといえる。

5.3 ボルト軸力の挙動

この種の梁では，フランジ面が曲げ応力を，ウェブ面 が剪断応力を分担するという考え方から, 荷重増加に伴 ならボルト軸力の低減現象は，実験Ｉではウェブ面に， 実験 II ではフランジ・ウェブ両面に起ることは予想さ れたところであるが，その低下量または低下率に関する フランジ面とウェブ面の差違は，今まで明らかではなか った。ただ梁の変形状態から推測すると，あるいはフラ ンジ面の方がウェブ面より大きくなるのではないかと考 えられた。

ところが，本実験の結果からは，両者に殆んど差のな いことが分った。このことは，剪断応力の局部集中によ る剪断変形量が無視できないことと，曲げ変形に引きず られてウェブ面の変形も進むことを意味していると思わ れる。また曲げによる远りの場合，ウェブ部のボルトも 抵抗していることが示され，当然の事ながら一般応力状 態時のフランジ部，ウェブ部の忍力分担を確然と分ける ことは難しい。

\section{4 繰返し荷重による影響}

実験Iでは，繰返し初期に扮いては迄り現象は出現し なかったのに，終期になると極く小さい変形による之り 現象が表われる。これは繰返しによるウェブ摩擦面の表 面性状の変化が原因と思われる。

実験 II では, BS 2 の第7サイクル（主过りの次の逆 載荷時)で $25.3 \mathrm{t}$ (主过り荷重 $33.2 \mathrm{t}$ ) の時に迄りを生 しており，BS 3 の第 7 サイクルでも 28.3 tの時に亡り 
が現われている。これは絽返し曲げ荷重試験において, サイクルが進むにつれてれり荷重が低下するという現象 とよく似ており，一般応力状態におけるフランジ部分が 繰返し曲げ応力を受けるために生起したものと判断でき る。従って実験Iの場合と総合して考えると高力ボルト 掱攃接合継手の場合は，一旦远るか，または之り近くま で載荷されると，それに伴なら部材の変形と摩擦面の状 態変化が，繰返し載荷によりえり荷重の漸減を生ぜしめ るものと推定される。

繰返し荷重によるボルト軸力の変化は，フランジ部で 绀荷重の増減に応じた挙動を示すが，ウェブ部では順次 低下していく一方で荷重逆転による増加現象は認められ なか子た。

梁の岡性は部材の降伏を伴なわない限り繰返しによっ て低下することは殆んどないといえる。

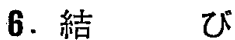

高力ボルト摩擦接合梁継手に, 繰返し曲げ待重, 繰返 几剪断荷重および繰返し曲げ，剪断両荷重を加えた時の 挙動に関し一連のものとして第1報に引き続き報告した わけであるが今回の実験で明らかになったのは次の諸点 である。

1）剪断型荷重試験による継手部の性状は；ウェブ部 ボルトの挙動に現われるが，フランジ部が充分に接合さ 肌ている限り，元りによる変形忹抑制され，終局強度は 氻なり高く評価してもよさそらである。

2）曲げと剪断が同時にかかる一般の応力状態では， フランジ部ボルトが曲げに，ウェブ部ボルトが剪断に抵 抗するものとして計算して差支えない。この場合ウェブ 部ボルトも曲げに抵抗するので，その分だけ曲げ抵抗に
余力があると考えられる。

3こうした継手部の弾塑性性状を論ずる場合，変形 量に着目すると曲げ応力による亡りに支配されることは 明らかであり，変形曲線の安定化のためには穴のクリア ランスをなるべく小さくする必要があろう。

4）接合部の強度，剛性に関しては剪断のみの場合も 曲げと剪断を同時に受ける場合も，曲げのみの場合と同 ごく非常に高性能が期待できる。

5）一般の応力状態に挍ける繰返しの場合に，曲げ荷 重時に現われたのと同様なえり部重の低下現象が認めら れたことは注目すべき事項である。

以上本実験の範囲内で，考光られる事柄であるが，何 分資料数も少なく複雑な摩擦接合機構の事でもあり，今 後検討す心゙き点も多々あると思われるので，皆様の御批 判を乞ら次第である。

本実験研究については，引続き東京工業大学藤本盛久 教授から㦝切な御指導を受け，また実験実施には東京工 業大学大学院生守谷, 大熊, 小南, 鈴木の諸君の御協力 を得た。ここに心から謝意を表する次第である。

\section{参考 文 献}

1) 北後 寿, 藤本盛久, 橋本篤秀：高力ボルト摩擦接合梁 の繰返し荷重試験，学会論文報告号外（昭 40.9）

2) 北 後表, 藤本盛久, 橋本篤秀：高力ボルト摩擦接合梁 の繰返し荷重試験（続），学会論文報告号外（昭 41.10）

3) 五十峲定義, 河田䔩治：高力ボルト摩擦接合部の挙動, “大工学集報, 39 巻 2 号 (昭 41.8)

4). 山田 稔, 仲座 巌, 都出 清 : リベットおよび高力ボル トの塑性疲労，学会諭文報告号外（昭 41.10）

5）北後 寿，橋本篤秀：高力ボルト摩擦接合ならびに同接 合法による 梁継手の弾塑性性状とその安全性に関する実 験的研究 (1), 学会諭文報告集 128 号 (昭 41.10) 


\title{
TRANSACTIONS OF THE ARCHITECTURAL
}

\author{
INSTITUTE OF JAPAN
}

\section{S Y N OPS IS}

U.D.C. $624.014 .5: 624.042$

\section{STUDIES ON BEAMS SUBJECT TO BENDING MOMENT AND SHEARING FORCE (Part 2)}

by Dr. YOSHITSURA YOKOO, Prof. of Kyoto Univ.

Dr. MINORU WAKABAYASHI, Prof. of Kyoto Univ. and Dr. YASUYOSHI SUENAGA Assistant Prof. of Yokohama National Univ. Members of A.I.J.

The Shearing members of steel concrete and composite structure have been almost structure consist of latticed steel.

However, recently according to development of welding process filled type steel members, welded members of plate, beam, column constructed with all welded structure, and $H$-shape steel, are going to be applied economically.

The purposes of this study are to investigate phenomena of failure on shearing registance of filled type steelconcrete used $H$-shape steel, furthermore, relation of thickness of steel web, to first diagonal cracks, and ultimate shearing strength, and consider increasing of ultimate strength, and the tenacity to deformation until failure.

U.D.C. 624.042 .4

\section{THE SPECTRUM OF WIND PRESSURE FLUCTUATIONS ON STRUCTURES IN WIND}

\author{
by Dr. HATSUO ISHIZAKI, Prof., Kyoto Univ., \\ CHANGGOO HUH, Reserch Student, Kyoto \\ Univ., Members of A.I,J.
}

The wind pressure fluctuations on structures are very complicated because wind is disturbed by structures and wind itself changes its direction and velocity, so it is not easy to know their nature clearly. In order to get imformations of wind load on structures, it measured that wind pressure fluctuations on walls and roofs of an existing house, then from the test data the power spectra of wind pressure fluctuations are computed. The measurements are carried out against the seasonal wind at Shionomisaki Wind Effect Labolatory of Kyoto Univ. on Feb. $23 \mathrm{rd}$ and Mar. 17th in 1963. Refference wind velocity is $5 \mathrm{~m} / \mathrm{sec}$ to $18 \mathrm{~m} / \mathrm{sec}$ at the point $10 \mathrm{~m}$ high above the ground level. There is on open field on the windward side of the house. The results show that the power spectra on the windward walls are similar to that of refference wind having no peak value at any period of pressure fluctuations. On the other hand it will be noted that the peak values are observed in the case of those on roofs or eaves at the period of $0.2 \mathrm{sec}$ to $0.3 \mathrm{sec}$, which shows that on roofs or eaves vortices break out periodically and that the pressure fluctuations there are affected mainly by the house form more than the turbulence of natural wind. The period of $0.2 \mathrm{sec}$ to $0.3 \mathrm{sec}$ at which the power spectra take peak values, is expected to be shorter when the refference wind speed becomes faster.

U.D.C. $624.078 .2: 620.174$

THE EXPERIMENTAL STUDY OF THE ELASTO-PLASTIC BEHAVIOR OF HIGH-TENSILE-BOLTED FRICTION JOINTS AND OF BEAMS WITH SUCH JOINTS (Part 2)

(Cyclic Loading Tests on Beam Joints)

by HISASHI HOKUGO, Director of Building Engineering Section, Electrical Communication Laboratory, N.T.T. and ATSUHIDE HASHIMOTO, Graduate Student, Tokyo Institute of Technology, Members of A.I.J. 
The authors reported on the experimental results of this thema under repeated pure bending in Part-1 (No. 128 Oct. 1966). And this report concerns two test executed afterwards under different condition : under pure shear and under bending and shear.

Some of the result are as following;

1) Under pure shear :

The load deflection curves are nearly the same as that for the joint-less beam till the first major slip and show very limited deformation at each slip.

The major slip occurs at the web splices. But the deformation is very small as long as the flange splices are securely connected, and there is ample reserve capacity beyond the first major slip.

The clamping force in the web bolts tends to decrease with increasing load similarly in the flange bolts under pure bending.

2) Under bending and shear (i.e. General condition):

The rigidity of high-tensile-bolt-jointed beams is very high and is almost the same as a joint-less beam.

The strength of the joints may be defined by the load at the first major slip, and it may be occured at the flanges by bending stress.

The clamping force in the bolts tends to decrease with increasing load, that of the flanges by bending and of the webs by shear.

The load of first major slip tends to declease with repetition of loading. This phenomena is recognized at the cas of both pure. bending and pure shear.

U.D.C. $624.014 .2: 539.37$

\section{RESEARCH ON THE ELAST-PLASTIC ANALYSIS OF STEEL SECTION SUBJECTED TO ALTERNATIVE LOAD (Part 5)}

by HIROTO HAgURA, Assistant. Prof.,

Chiba Institute of Technology, Member of A.I.J.

In this paper, author analyzed rectanguler section subjected to constant bending moment and alternative axia! forces, using the method descrived in the preceding paper (See part 1-4).

Cases when the axial forces were unloaded at the elasto-plastic state (2), an incremental collapse phenomenon will occure, causing gradual increasing of bending curvature.

As mentioned above, author propose "A hypothesis of Shake-Down Load", in cases of symmetrical sections subjected alternative loads.

Then, in order to determine the differences due to the loading sequence, author analyzed the following cases;

12.1 Proportional loads.

12.2 Cases when bending moment is applied after the application of axial forces.

12.3 Cases when axial forces are applied after the application of bending moment, when the bending is within the elastic range.

12.4 Cases when axial forces are applied after the application of a bending moment, when the bending is in elasto-plastic range.

The same results are obtained for $12.1,12.2$ and 12.3 , but the results for 12.4 do not show correspondence because elasto-plastic antecedents are aplied by bendings.

U.D.C. $624.014 .5: 624.078$

STUDY ON THE LIMITATION OF WIDTH-THICKNESS RATIO IN PLASTIC HINGES (5)

by Dr. HISASHI TANAKA, Associate Prof. of Tokyo Univ., KOHICHI TAKANASHI, Lecture of Tokyo

Univ., Members of A.I.J.

It is widely known that the results of plastic buckling tests of plates are well correlated by a simple total or deformation theory, but not by an incremental or flow theory which is theoretically, experimentally recognized to be valid. Onat and Drucker, however, demonstrated in a simple example that extremely small, and therefore unavoidable imperfections of shape do account for the paradox.

In previous authors' papers, there are discussed uniqueness and stability in elastic-plstic plates; in the case of the long rectangular plate hinged along one edge and free on the other under uniform compressive stress at the ends, it was examined how much the imperfection influence the stability limit.

At the standpoint of Plastic Design, however, the initiation of excessive deformation or deflection of plates has to be offered attention rather than the stability limit. Therefore we have to discuss load-deflection behaviors of plates at the presence of initial deflections. The load-deflction behavior can be obtained by solving a rate problem which takes account of the geometry changes in step by step procedure.

In this paper, the whole curves of load versus deflection of a solid plate under the above mentioned boundary and loading conditions are shown, and then a large amount of discrepancy between the theoretical plastic buckling load and the load corresponding to the initiation of excessive deflection is revealed. 